\title{
Morphological and functional characterization of bovine oviductal epithelial cell monolayers cultured on polarizing membranes
}

\author{
E Gómez ${ }^{1 *}, \mathrm{H}$ Uría ${ }^{2}$ \\ ${ }^{1}$ Centro de investigación aplicada agraria y tecnología agroalimentaria, \\ centro de selección y reproducción animal, Aptdo 155, 33203 Gijón; \\ ${ }^{2}$ Departamento de morfología y biología celular, facultad de medicina, \\ C/ Julian Claveria s/n. Universidad de Oviedo, 33006 Oviedo, Asturias, Spain
}

(Received 29 May 1996; accepted 18 November 1996)

\begin{abstract}
Summary - Several characteristics of oviductal cells, cultured under either polarizing or nonpolarizing conditions, were studied. In vitro produced bovine embryos tested the embryotrophic abilities of the respective conditioned media. Conditioned medium from the apical face of polarized cell monolayers supported higher rates of development to blastocyst and expanded blastocysts. In contrast, conditioned medium from the basal face supported embryo development only to the 816 cell stage; however, these embryos were able to continue development to the morula stage when cultured in medium from the apical and basal faces, indicating total cell confluence and a clear functional polarization. At the ultrastructural level, cells cultured in polarizing conditions displayed characteristics nearer to the same cells in vivo and signs of a metabolic activity higher than that in cells cultured under non-polarizing conditions. It can be concluded that cell-polarization, in our culture conditions, is beneficial to embryo development.
\end{abstract}

bovine / in vivo / embryo / oviduct / polarization

Résumé - Caractéristiques morphologiques et fonctionnelles des cellules oviductales bovines cultivées sur membranes de polarisation. Des embryons bovins produits in vitro ont été utilisés pour évaluer l'activité embryotrophique de deux milieux conditionnés obtenus à partir de cellules d'oviducte cultivées en monocouche, avec ou sans polarisation. On a étudié aussi certaines caractéristiques de ces tapis cellulaires. Les taux de blastocystes et de blastocystes expansés ont été plus élevés avec le milieu conditionné obtenu à partir de la surface apicale de la monocouche cellulaire. Le milieu conditionné issu de la surface basale a permis le développement jusqu'au stade 8-cellules, mais ces embryons se sont développés ultérieurement en présence de milieu conditionné provenant du côté apical. Les deux milieux conditionnés présentaient un $\mathrm{pH}$ et des concentrations de lactate signi-

* Correspondence and reprints.

Tel: (34) 8 5195300; fax: (34) 85195310 
ficativement différents. Au niveau ultrastructural, les cellules cultivées dans des conditions polarisées ont montré des caractéristiques très proches de celles des cellules in vivo, ainsi que des signes d'une activité supérieure à celle des cellules produites dans des conditions non polarisées. Nous pouvons conclure que, dans nos conditions de culture, la polarisation de la monocouche de cellules d'oviducte améliore le développement des embryons bovins produits in vitro.

bovine / in vitro / embryon / oviducte / polarisation

\section{INTRODUCTION}

The development of an efficient system to produce high percentages of good quality bovine blastocysts in vitro is an important goal of reproductive research. As a consequence, a wide variety of culture systems, including bovine oviductal epithelial cell (BOEC) cocultures (Eyestone and First, 1989; Gandolfi and Moor, 1987; Xu et al, 1992) and their corresponding conditioned media (Eyestone and First 1989; Gandolfi and Moor, 1987; Ellington et al, 1990; Hernández-Ledezma et al, 1995; Vansteenbrugge et al, 1992; Mermillod et al, 1993) have been used with unequal results, translated as total, expanded and hatched blastocyst rates lower than in co-cultures (Ellington et al, 1990; Hernández-Ledezma et al, 1995) and a high variability of the embryotrophic activity among different batches of conditioned media (Vansteenbrugge et al, 1992). Limited efforts to improve in vitro embryo production have been focused on cell-polarizing in co-cultures, possibly because high levels of cell polarization were not required for the beneficial effects of coculture to occur (Ouhibi et al, 1990; McCaffrey et al, 1991). Polarized cultured BOEC on matrigel coating showed morphological and functional features resembling those of intact epithelial cells (Ouhibi et al, 1990; McCaffrey et al, 1991; Eyestone et al, 1991; Joshi, 1991) even with spontaneous tubeshaped organization (Joshi, 1991) and a yield of blastocysts, co-cultured on frozen/thawed cell-monolayers, exhibiting a number of cells higher than that from nonpolarized cultured BOEC (Da Silva, 1994). Spermatozoa were able to bind more effi- ciently to polarized BOEC than to the same non-polarized cells (Pollard et al, 1991; Ellington et al, 1993). Sera are needed for cell attachment and growth, but they add unpredictable effects. Serum-free conditioned medium obtained from polarized BOEC could be an appropriate system to culture in vitro produced bovine embryos and could exhibit different functional traits as a consequence of the different cell organization. The aims of this work were: 1) to test the embryotrophic activity from the corresponding apical and basal conditioned media; 2) to determine the cell-monolayer ability to establish a secretory differentiation between apical and basal faces, by taking into account values of $\mathrm{pH}$ and concentrations of lactate (lactate is a molecule having a molecular mass lower than $0.5 \mathrm{KDa}$, which is the pore size limit of the membrane employed. Therefore, lactate could flow freely across the membrane region(s) where the cells were not present); and 3) to investigate morphological changes in BOEC cultured as a monolayer grown on a porous substrate (inserts), compared to classical non-polarized culture conditions.

\section{MATERIALS AND METHODS}

\section{Preparation of cell monolayers and exoge- nous protein-free bovine oviductal epithe- lial cell conditioned media (BOECM)}

Oviducts were taken at slaughterhouse from cows previously diagnosed in standing estrus in vivo, and whose status was confirmed by the postmortem observation of cervical mucus, ovaries with the absence of a corpus luteum and the pres- 
ence of a large follicle $(>1.5 \mathrm{~cm})$ (Eyestone et al, 1990). Some other oviducts corresponding to ovaries showing a haemorragic corpus luteum were also used (Durnford et al, 1994). Oviducts were transported to the laboratory within $2 \mathrm{~h}$ at room temperature in plastic bags. BOECM was prepared essentially according to the procedures reported by Eyestone and First (1989). Briefly, oviducts were freed from adjacent tissues and treated for $30 \mathrm{sec}$ in ethanol $(70 \% \mathrm{v} / \mathrm{v})$ in water. Mechanical pressure with a glass slide along the oviduct allowed the collection of epithelial cells (Van Langendonckt et al, 1995) which were dispersed by passing through a $25 \mathrm{G}$ needle attached to a syringe. The cells were pooled in a $15 \mathrm{~mL}$ polystyrene centrifuge tube and sedimentationwashed four times in oocyte holding medium (HM) containing PBS, BSA $\left(0.4 \mathrm{mg} \cdot \mathrm{mL}^{-1}\right.$; Sigma, Madrid, Spain), sodium-pyruvate $(0.3 \mathrm{mM})$ and gentamicin sulfate solution ( $5 \mu \mathrm{L} \cdot \mathrm{mL}^{-1}$; Gibco, Paisley, Scotland) and then washed again in culture medium (CM), that consisted of M-199 with Earle's salts, L-glutamine and sodium bicarbonate $\left(1.25 \mathrm{~g} \cdot \mathrm{L}^{-1}\right.$; Gibco), estrous cow serum $(10 \% \mathrm{v} / \mathrm{v}$, from normally cyclic single cows and heat-inactivated) and gentamicin. The final cell pellet was resuspended in 50 volumes of $\mathrm{CM}$ and aliquots of cell-suspension were seeded: 1$)$ in 4-well dishes $(400 \mu \mathrm{L} /$ well Nunc, Roskilde, Denmark -, non-polarizing conditions); or 2) on the basement membrane of tissue culture inserts $(1.2 \mathrm{~mL}$ per insert $0.2 / 0.02 \mu \mathrm{m}$ pore size, Nunc -, polarizing conditions, treatment $\mathrm{IN}$ ). For the latter culture group, $2.3 \mathrm{~mL}$ of $\mathrm{CM}$ without cells were added to the space between the insert and the recipient well (6well plates, Nunc, treatment OUT). Incubation conditions of $39^{\circ} \mathrm{C}, 5 \% \mathrm{CO}_{2}$ in air and high humidity, were maintained for all the experiment. Renewing of CM was as follows:

- non polarizing conditions: the culture medium was renewed 3-4 days after seeding and attached cells were allowed to grow for a further period of 3 days to allow formation of a confluent monolayer; the cells were then cultured for $24 \mathrm{~h}$ in M-199 alone to allow the cells to eliminate the remaining serum fractions; the medium was aspirated and discarded and cell-monolayers rinsed once with M-199 alone, of which $400 \mu \mathrm{L}$ were used per well for a conditioning period of $48 \mathrm{~h}$;

- polarizing conditions: complete cell-confluence was observed, in all cases, in 48-72 h after seeding, time at which the first renewing was made; the other steps were as in non-polar- izing conditions, but using the appropriate volumes of $\mathrm{CM}$.

The three types of recovered BOECM (nonpolarizing, IN and OUT), were centrifuged $(500 \mathrm{~g})$; the supernatant was stored frozen $\left(-18^{\circ} \mathrm{C}\right)$ in aliquots until used for embryo culture (Eyestone et al, 1991; Mermillod et al, 1993) (experiment 1). Some other samples were utilized fresh for $\mathrm{pH}$ determination or frozen/thawed for lactate determination (experiment 2). Cellsmonolayers were then used for morphological analysis (experiment 3 ).

\section{Experiment 1}

\section{Testing embryotrophic ability of the con- ditioned media}

\section{Oocyte recovery and maturation}

Ovaries recovered from slaughtered Asturiana de los Valles and Holstein Friesian cows and heifers were placed in physiological saline containing antibiotics (penicillin: 100 units $\mathrm{mL}^{-1}$ and streptomycin sulfate: $100 \mathrm{mg} \cdot \mathrm{mL}^{-1}$ ) and maintained at $30-33{ }^{\circ} \mathrm{C}$ for $3 \mathrm{~h}$ approximately until cumulus-oocyte complexes (COCs) recovery. Ovaries were washed twice in distilled water and once in freshly prepared saline with antibiotics. COCs were aspirated from 2 to $7 \mathrm{~mm}$ antral follicles through an $18 \mathrm{G}$ needle connected to a vacuum system and recovered in a $50 \mathrm{~mL}$ plastic tube (Nunc). FF and COCs were put into an ovum concentrator (Em-Con, Eurofomento Pecuario, Madrid, Spain) (Hawk and Wall, 1994) and rinsed three times with HM. Only oocytes with evenly granulated cytoplasm which were enclosed in compact cumulus were selected for maturation. COCs were washed three times in maturation medium (medium 199 + estrous cow serum: $10 \% \mathrm{v} / \mathrm{v}$ and $\mathrm{pFSH}: 20 \mu \mathrm{g} \cdot \mathrm{mL}^{-1}$, Schering-Plough Animal, Health, Madrid, Spain) (Saeki et al, 1990). Maturation was performed by culturing approximately $100 \mathrm{COCs}$ in $500 \mu \mathrm{L}$ of maturation medium in four-well dishes.

\section{In vitro fertilization}

In vitro fertilization was carried out by using procedures similar to those previously reported by Parrish et al (1986) on the basis of a modified Tyrode's lactate solution (TALP). Frozen semen from a single bull was thawed, transferred to the 
top of a Percoll $45 \%-90 \%$ gradient, and centrifuged at $700 \mathrm{~g}$ for $30 \mathrm{~min}$. The sperm pellet was diluted with $5 \mathrm{~mL}$ of Sp-TALP (pH 7.4, with $10.0 \mathrm{mM}$ Hepes, $25 \mathrm{mM}$ bicarbonate, $21.6 \mathrm{mM}$ lactate and $1.0 \mathrm{mM}$ pyruvate), centrifuged for $10 \mathrm{~min}$ at $200 \mathrm{~g}$ and the supernatant aspirated to leave a pellet approximately $100 \mu \mathrm{L}$ in volume. Sperm concentration was determined with an haemocytometer. Fertilization medium (FertTALP: $\mathrm{pH} 7.8$, with $25 \mathrm{mM}$ bicarbonate, $10 \mathrm{mM}$ lactate and $0.2 \mathrm{mM}$ pyruvate; heparin: $10 \mathrm{mg} \cdot \mathrm{mL}^{-1}$, Sigma) was used to dilute sperm. After 22-24 h of maturation, COCs were washed three times in Wash-TALP (pH 7.4, with $10.0 \mathrm{mM}$ Hepes, $2.0 \mathrm{mM}$ bicarbonate, $10 \mathrm{mM}$ lactate and $0.2 \mathrm{mM}$ pyruvate) and placed in fourwell culture dishes $(100 \mathrm{COCs} /$ well $)$ containing preequilibrated fertilization medium. Spermatozoa were then added to each well to reach a concentration of, approximately, $2 \times 10^{6} \mathrm{sp} / \mathrm{mL}$ in $500 \mu \mathrm{L}$ of medium. Sperm and COCs were coincubated for $18 \mathrm{~h}$.

\section{In vitro embryo culture}

Aliquots of conditioned media were thawed at room temperature and centrifuged. The sediment was discarded and 30-50 $\mu \mathrm{L}$ droplets $(1 \mu \mathrm{L}$ embryo) were prepared in culture 4-well dishes under mineral oil and equilibrated in the incubator for at least $2 \mathrm{~h}$ before the addition of the zygotes. Fertilized oocytes were vortexed for 2 min in HM at medium speed to separate cumulus cells and rapidly washed three times in HM and twice in the appropriate culture medium prior to a 9 day period of culture.

\section{Experiment 2}

\section{Determination of the ability of $\mathrm{BOEC}$ - monolayers to avoid the free exchange of molecules between apical and basal con- ditioned media}

\section{Determination of $\mathrm{pH}$ in the conditioned media}

Several samples of the different BOECM (IN, OUT and non-polarizing) were used for $\mathrm{pH}$ determinations at $48 \mathrm{~h}$ of the conditioning period. Small quantities ( $2 \mathrm{~mL}$ each, approximately) of BOECM were put to equilibrate in $15 \mathrm{~mL}$ plastic polystyrene centrifuge tubes placed into the incubator for at least $1 \mathrm{~h}$. The $\mathrm{pH}$ was measured (Piccolo ATC pHmeter, Hanna Instruments, Woonsocket, USA) $30 \mathrm{sec}$ after each tube containing BOECM was taken out of the incubator.

\section{Determination of the concentrations of} lactate in the conditioned media

Lactate concentrations were determined at 24 and $48 \mathrm{~h}$ of conditioning by a reverse phase HPLC modified method previously described (Blanco Gomis et al, 1988). Prior to the chromatographic analysis, the samples were microfiltered and eluted through a $\mathrm{C}_{18}$ phase to retain colourings (phenol red) and the most lipophylic fractions. Absorption at $206 \mathrm{~nm}$ was the detection system employed.

\section{Experiment 3}

\section{Morphological analysis of cultured bovine oviductal epithelial cells-monolayers}

Bovine oviductal epithelial cells taken at the end of the $48 \mathrm{~h}$ conditioning period, cultured in 4well dishes (9-10 days old) or on inserts (5-6 days old) were gently washed twice with PBS. The cells were fixed overnight at $4{ }^{\circ} \mathrm{C}$ with $3 \%$ glutaraldehyde (Fluka, Madrid, Spain) in $\mathrm{pH}$ $7.4 \mathrm{PBS}$ containing $\left.\mathrm{CaCl}_{2} \cdot 2 \mathrm{H}_{2} \mathrm{O}(0.013 \%) \mathrm{w} / \mathrm{v}\right)$, $\mathrm{MgCl}_{2} \cdot 6 \mathrm{H}_{2} \mathrm{O}(0.01 \% \mathrm{w} / \mathrm{v})$ and postfixed with $1 \% \mathrm{OsO}_{4}$ (Sigma) in PBS for $35 \mathrm{~min}$ at room temperature. All plates and inserts containing the cells were rinsed with PBS and stored at $4{ }^{\circ} \mathrm{C}$. The buffer solution was replaced four times over the subsequent $36 \mathrm{~h}$ in order to remove the unreacted osmium tetroxide absorbed by the polystyrene. Finally, the cells were dehydrated in an ascending series of methanol and embedded in Epon 812 (Electron Microscopy Sciences, PA, USA). Semi-thin sections ( $1 \mathrm{~mm})$, obtained with an ultracut $\mathrm{E}$ (Reichert Jung, Austria) ultratome, were stained with toluidine blue (Gurr-BDH Chemicals Limited, Poole, England) and studied and photographied with a Orthoplan microscope (Ernst Leitz Wetzlar Gmbh, Germany). Thin sections were cut with a diamond knife DDK (Delaware Diamond Knives, Delaware, USA) on an ultramicrotome (MT7, Research \& manufacturing Company, Inc, Tucson, Arizona, USA), counterstained with uranyl acetate-lead citrate and examined under a transmission electron microscope (EM-109, Carl Zeiss, Germany) operating at $50 \mathrm{kV}$. 


\section{Experimental design and statistical analysis}

Presumptive zygotes were randomly allocated to each of the experimental treatments. Embryo development was assessed on days $3,7,8$ and 9 of culture (day 1 = start of culture) and proportions of different stages of embryo development were recorded as seen in table $\mathbf{I}$. The number of replicates for both embryo development and $\mathrm{pH}$ of conditioned media was variable and depended on previous results. Determination of lactate concentrations was made in three replicates. Comparisons for embryo development were made by GLM procedure and subsequent REGWF-test for means. Comparisons for $\mathrm{pH}$ and lactate values were made by a paired observations $F$-test. Data are presented as the mean \pm SEM.

\section{RESULTS}

\section{Experiment 1}

Development rates are shown in table I. Both total and expanded blastocyst productions were significantly higher $(P<0.05)$ in conditioned medium IN than in all the other groups. Blastocyst hatching occurred in IN (1.19 \pm 0.75 ; data not shown), while the other treatments did not generate hatched embryos. Embryos cultured in OUT arrested development between third and fourth cell cycles, although continued to morula when further cultured in IN (OUT > IN treatment).

\section{Experiment 2}

The results of experiment 2 are shown in tables II and III. In table II, $\mathrm{pH}$ values were significantly lower for OUT vs IN conditioned media $(P<0.01)$. In table III, lactate concentrations varied between time periods (24 and $48 \mathrm{~h})$ significantly for IN $(P<0.01)$, IN + OUT $(P<0.05$; data not shown $)$ and not significantly for OUT $(P<0.06)$ treatments, and within the $24 \mathrm{~h}$ period between IN and OUT $(P<0.05)$ treatments and between non-polarizing and both IN and OUT $(P<0.01)$ treatments.

Table I. Development up to expanded blastocyst stage of in vitro produced bovine embryos cultured in different bovine oviductal epithelial cell conditioned media.

\begin{tabular}{|c|c|c|c|c|c|c|c|}
\hline \multirow[b]{2}{*}{ Treatment } & \multirow[b]{2}{*}{$\operatorname{Rep}$} & \multirow[b]{2}{*}{$N$} & \multirow[b]{2}{*}{ Cleaved } & \multirow{2}{*}{$\begin{array}{c}5-8 \\
\text { cells } \\
\%\end{array}$} & \multirow[b]{2}{*}{$\begin{array}{c}\text { Morula } \\
\%\end{array}$} & \multicolumn{2}{|c|}{ Blastocysts } \\
\hline & & & & & & Total & $\begin{array}{l}\text { Expanded } \\
\%\end{array}$ \\
\hline $\begin{array}{l}\text { Non } \\
\text { polarizing }\end{array}$ & 8 & 203 & $\begin{array}{l}76.84^{\mathrm{a}} \\
\pm 5.89\end{array}$ & $\begin{array}{l}46.14 \\
\pm 7.12\end{array}$ & $\begin{array}{l}21.78^{\mathrm{a}} \\
\pm 3.05\end{array}$ & $\begin{array}{l}5.76^{\mathrm{a}} \\
\pm 1.90\end{array}$ & $\begin{array}{r}1.91^{\mathrm{a}} \\
\pm 1.39\end{array}$ \\
\hline IN & 8 & 202 & $\begin{array}{l}70.29^{a} \\
\pm 3.16\end{array}$ & $\begin{array}{l}45.07 \\
\pm 2.91\end{array}$ & $\begin{array}{l}23.23^{\mathrm{a}} \\
\pm 2.30\end{array}$ & $\begin{array}{l}12.67^{\mathrm{b}} \\
\pm 2.32\end{array}$ & $\begin{array}{l}8.45^{\mathrm{b}} \\
\pm 2.11\end{array}$ \\
\hline OUT & 7 & 150 & $\begin{array}{l}68.66^{\mathrm{a}} \\
\pm 8.09\end{array}$ & $\begin{array}{l}46.60 \\
\pm 2.50\end{array}$ & $0.00^{\mathrm{b}}$ & 0.00 & 0.00 \\
\hline OUT $>$ IN & 4 & 88 & $\begin{array}{l}77.27^{\mathrm{a}} \\
\pm 8.62\end{array}$ & $\begin{array}{r}42.64 \\
\pm 3.00\end{array}$ & $\begin{array}{l}20.50^{\mathrm{a}} \\
\pm 1.64\end{array}$ & $0.00^{\mathrm{c}}$ & 0.00 \\
\hline $\begin{array}{l}199 \\
\text { alone }\end{array}$ & 4 & 84 & $\begin{array}{l}38.09^{\mathrm{b}} \\
\pm 3.25\end{array}$ & $\begin{array}{l}40.60 \\
\pm 0.73\end{array}$ & $0.00^{\mathrm{b}}$ & 0.00 & 0.00 \\
\hline
\end{tabular}

IN: conditioned medium from the apical face. OUT: conditioned medium from the basement face. Non-polarizing: conditioned medium from non-polarized cells. Rep: number of replicates per treatment; $N$ : number of oocytes. Superscripts within the same column differ significantly: a,b,c $(P<0.05)$. Data are shown as means $\pm \mathrm{SE}$. All developmental stages beyond 'cleaved' are expressed as a \% of cleaved embryos. 
Table II. $\mathrm{pH}$ values of conditioned media from polarized (IN and OUT) and non polarized bovine oviductal epithelial cell monolayers.

\begin{tabular}{lcc} 
Treatment & $\begin{array}{c}\text { Samples } \\
\text { measured }\end{array}$ & $\begin{array}{c}\text { pH values } \\
(48 \mathrm{~h})\end{array}$ \\
\hline IN & 9 & $7.27 \pm 0.007^{\mathrm{x}}$ \\
OUT & 9 & $7.12 \pm 0.007^{\mathrm{y}}$ \\
Non polarizing & 6 & $7.28 \pm 0.005^{\mathrm{x}}$ \\
\hline
\end{tabular}

Data presented as means \pm SE. Superscripts in the same column represent significant differences: ${ }^{x}$ and $y$ $(P<0,01)$.

Table III. Values of lactate concentrations (mg. $\mathrm{mL}^{-1}$ ) after 24 and $48 \mathrm{~h}$ of culture in conditioned media from polarized (IN and OUT) and non-polarized bovine oviductal epithelial cell monolayers.

\begin{tabular}{cccc}
\hline Treatment & $\begin{array}{c}\text { Samples } \\
\text { measured }\end{array}$ & $24 \mathrm{~h}$ & $48 \mathrm{~h}$ \\
\hline
\end{tabular}

\begin{tabular}{llll} 
IN & 3 & $712 \pm 61^{\mathrm{axi}}$ & $349 \pm 37^{\mathrm{ii}}$ \\
OUT & 3 & $516 \pm 27^{\mathrm{bx}}$ & $362 \pm 51$ \\
Non & 3 & $240 \pm 12^{\mathrm{y}}$ & $289 \pm 33$ \\
polarizing & & & \\
\hline
\end{tabular}

Data presented as means \pm SE. Superscripts in the same column represent significant differences: ${ }^{a}$ and ${ }^{b}$ $(P<0.05){ }^{\mathrm{x}}$ and ${ }^{\mathrm{y}}(P<0,01)$.

Superscripts within the same line represent significant differences: ${ }^{\mathrm{i}}$ and ${ }^{\mathrm{ii}}(P<0.01)$

\section{Experiment 3}

In semi-thin sections, the cells cultured on 4well dishes clearly showed many clear vesicles disposed inside and among the cells (fig 1). In contrast, clear vesicles were scarcely seen in the cells growing on inserts (fig 2). BOEC cultured directly on dishes showed a single layer of cells (fig la) and a few basophilic bodies, whereas BOEC cultured in inserts showed several layers of cells (fig 2a) and many basophilic bodies (fig 2). At the ultrastructural level, most of
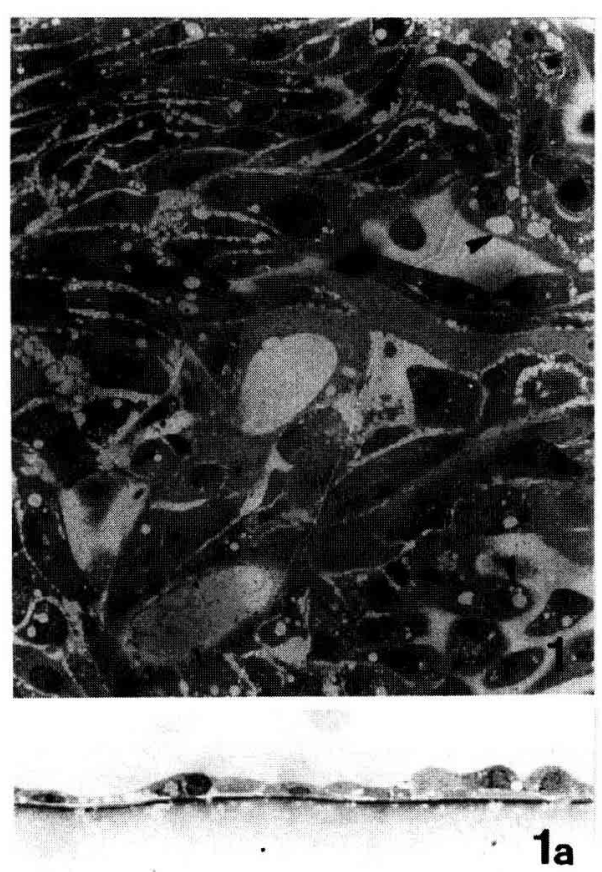

Fig 1. Semi-thin section of a confluent monolayer of epithelial cells growing on a plastic plate. Note the presence of numerous clear vesicles inside (arrowheads) and among the cells (arrow) $\times 310$

Fig 1a. Perpendicular semi-thin section of a confluent monolayer of epithelial cells growing on a plastic plate. $\times 310$

the BOEC cultured on dishes showed microvilli at the apical face, cell-to-cell junctions, mitochondria, Golgi complexes and a smooth contoured nucleus (fig 3). However, some of the cells grown on plastic presented a nucleus with a variable contour, a lower number of mitochondria, and several electron-clear vesicles in the cytoplasm (fig 4). The cells growing on inserts showed a compacted appearance with several layers of cells (figs 5 and 6), many desmosomes and several electron-dense areas, possibly developing junctions (fig 7). Usually, these junctions were seen in the apical membrane of the upper layer of cells. Numerous polyri- 

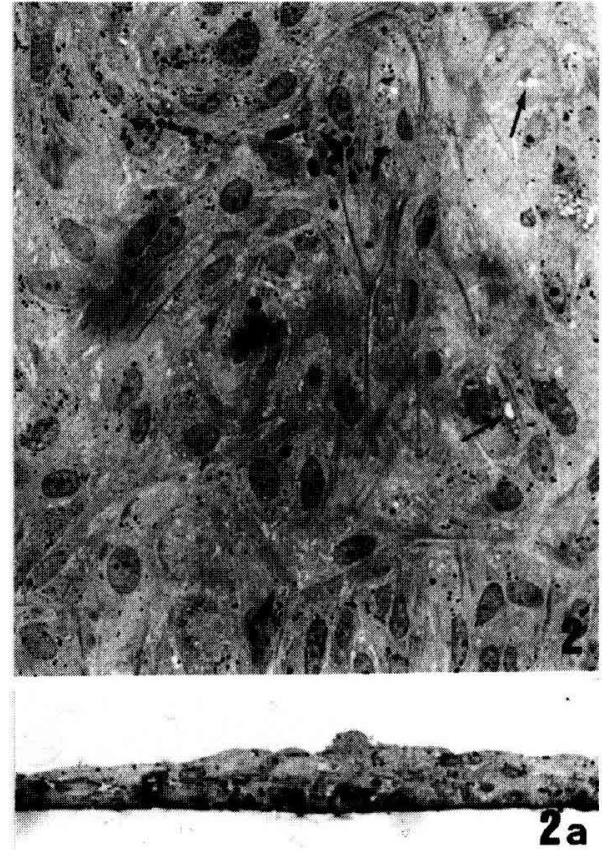

Fig 2. Semi-thin section of bovine epithelial cells growing on inserts. Observe the low number of clear vesicles (arrows) and the numerous basophilic bodies (arrowheads) dispersed in the cytoplasm of the cells. $\times 310$

Fig 2a. Perpendicular semi-thin section of bovine epithelial cells growing on inserts showing the existence of several layers of cells. $\times 310$

bosomes (fig 8), mitochondria, cisternae of the granular endoplasmic reticulum and a well-developed Golgi system appeared scattered within the cytoplasm (fig 7 and 9). Coated vesicles filled with moderately electron-dense material were also observed closely related to the apical cell membrane (fig 10). The cytoplasm of the cells grown on inserts contained a few electron-dense granules. These granules seem to be those described in semi-thin sections as basophilic bodies which, at high magnification, appear surrounded by a limiting membrane and composed of fine, granular, electron-dense material (fig 9 and 11). These granules were

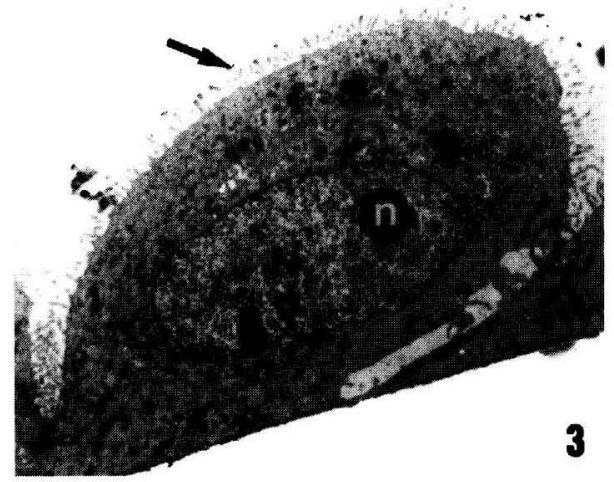

Fig 3. Electron micrograph of an epithelial cell growing on a plastic dish showing mitochondria (arrowheads), junctions (open circle), and microvilli (arrow) extending from cell apex, $\mathbf{N}$, nucleus, n, nucleolus. $\times 4000$

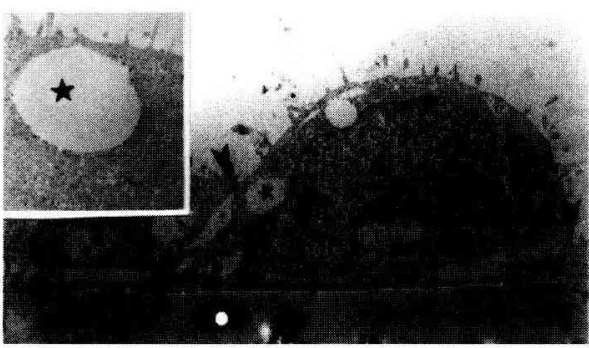

Fig 4. Perpendicular ultra-thin section of epithelial cells on plastic surface $(\mathbf{P})$. Observe the presence of several electron-clear vesicles (stars) in the cells. Junctions (arrowheads) $\times 5100$.

Inset: Detail of an electron-clear vesicle (star). $\times 7200$

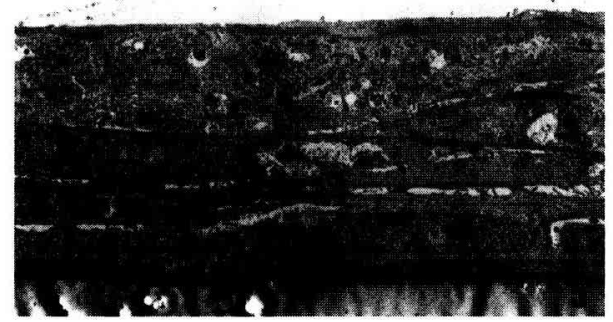

Fig 5. Perpendicular section of BOEC cultured in inserts showing several layers of cells with a flattened appearance. $\times 2700$ 


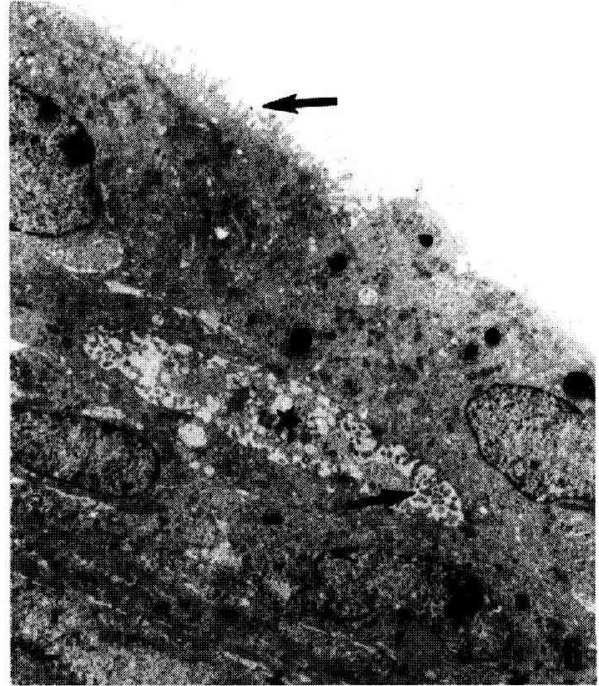

Fig 6. Electron micrograph of cells cultured on inserts. Note the presence of unhomogeneous material (star) in the free space among several cells. Microvilli (arrows) $\times 3600$

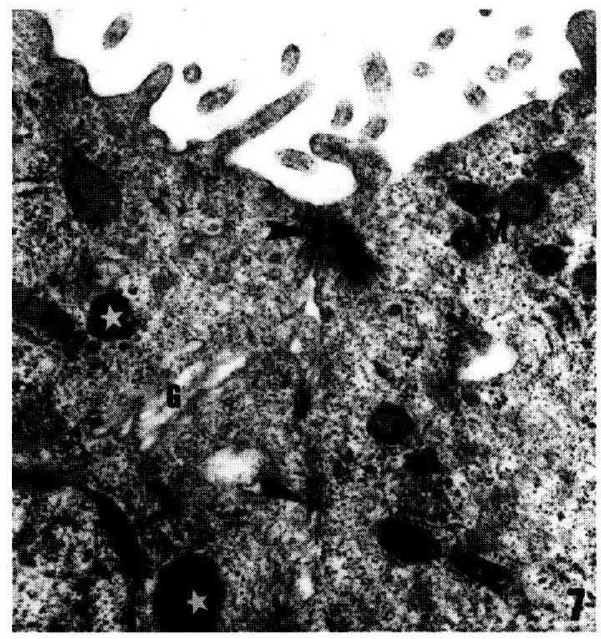

Fig 7. Apical zone of two epithelial cells showing several junctions (arrowheads), a well developed Golgi complex (G) and electron-dense granules (white stars). Note the presence of numerous mitochondria $(\mathbf{M}) \times 20500$

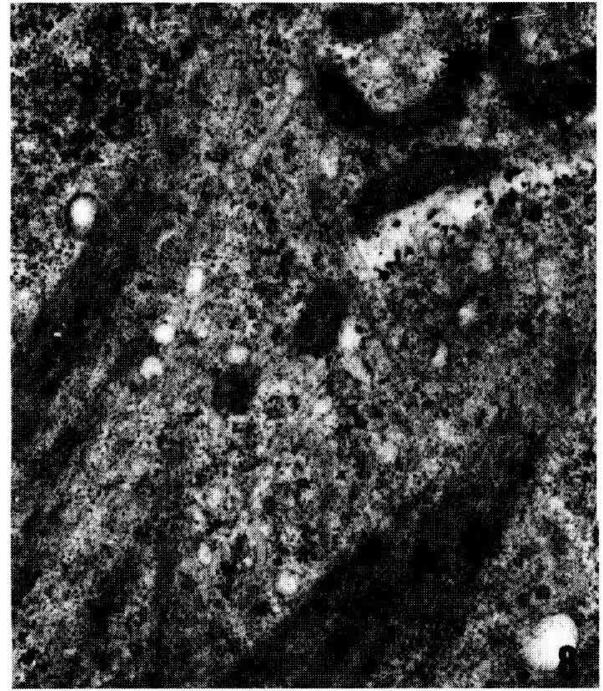

Fig 8. Electron micrograph of cells cultured on inserts showing cytoskeleton filaments (f), polysomes $(\mathbf{P})$, and mitochondria (star). $\times 22500$

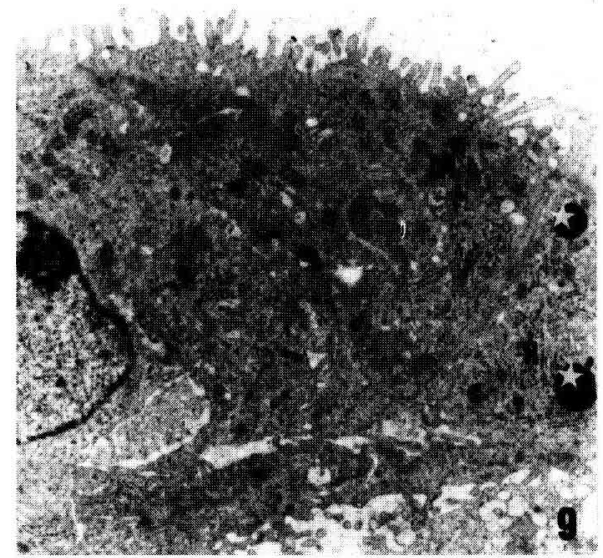

Fig 9. Detail at high magnification of figure 6 showing mitochondria $(\mathbf{M})$, rough endoplasmic reticulum $(\mathbf{R})$ and electron-dense granules (white stars). $\times 7600$ 


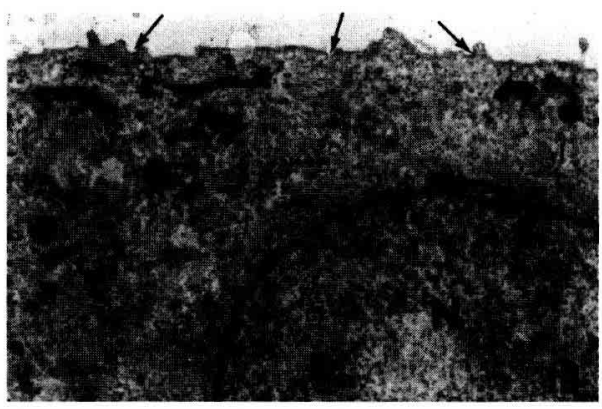

Fig 10. BOEC growing on insert. Observe the presence of several coated vesicles, close to the apical membrane (arrowheads), that contain material which is secreted out of the cell after vesicle incorporation to the cell membrane (arrows). $\mathbf{N}$, nucleus. $\times 8500$

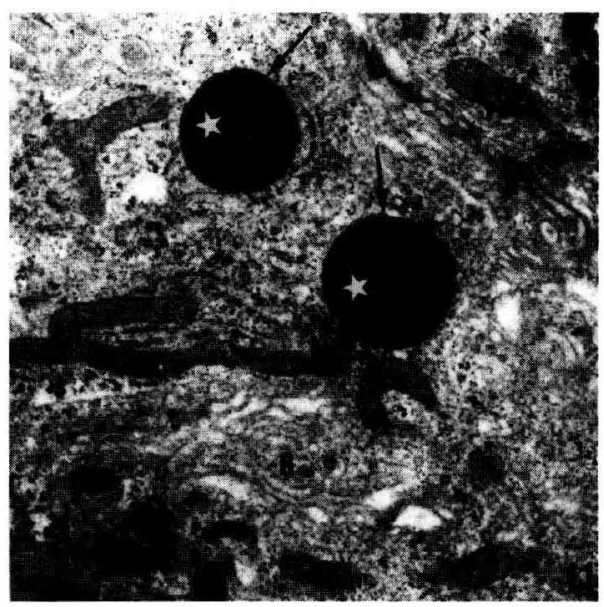

Fig 11. Detail at high magnification of BOEC cultured on inserts showing a well developed Golgi system $(\mathbf{G})$ and mitochondria (M) in the proximity of two electron-dense granules (white stars). Note the existence of a membrane in the periphery of the granules (arrows). $\mathbf{N}$, nucleus. $\times 20000$

not orientated to the cell surface, and it is difficult to distinguish if they are secretory granules or other dense bodies such as secondary lysosomes.

\section{DISCUSSION}

Although other authors have reported no beneficial effects of support cell polarization for the coculture of bovine embryos (Ouhibi et al 1990; McCaffrey et al, 1991), in the present study development to both blastocyst and expanded blastocyst stages increased when embryos were cultured in conditioned media recovered from the apical face of BOECs cultured on inserts (IN) compared to that collected under non-polarizing conditions $(P<0.05)$. Embryos cultured in medium conditioned by the basement face of insert (OUT) arrested development after the 8-cell stage had been reached. Further culture of these embryos, initially cultured in OUT conditioned medium, in IN conditioned medium improved development up to the morula stage, but no further. OUT-cultured embryos are unable to reach the blastocyst stage.

High molecular weight factors looked unnecessary during earlier development, but maybe they capacitate the embryo at these initial stages to proceed in good condition to later stages. Mermillod et al (1993), using conditioned M-199, reported a favourable effect of low molecular weight factors $(\leq 10 \mathrm{kDa})$ on development to the 8 -cell stage. These embryos cultured in ultrafiltrate-conditioned medium were not further cultured in whole conditioned medium, so their ability to normally develop is not completely defined. A low molecular weight positive conditioning on the earlier developmental stages has also been suggested in mouse (Minami et al, 1992) and more recently in human oviductal cells (Liu et al, 1995). In our work, the effect to the 8-cell stage is supported by molecules lower than $0.5 \mathrm{kDa}$, which significantly reduces the likelihood of finding molecules exerting a positive conditioning. Furthermore, no lumen-specific oviductal factors are involved, due to the basal origin of the conditioning. This could relate to previously reported detoxificant effects of helper cells 
(negative conditioning), in terms of removing or transforming glucose (Takahashi and First, 1992), some toxic components of M199 as hypoxanthine (Loutradis et al, 1987), phosphate (Pinyopummintr and Bavister, 1991) and superoxide radicals (Noda et al, 1991). Low molecular weight antioxidants, as taurine (Tiffin et al, 1991) and gluthatione (Legge and Sellens, 1991), could also have been secreted into the medium.

Cells cultured on inserts formed a confluent monolayer in 2-3 days, in contrast to that reported when other growth substrates are used (15-20 days in matrigel, Joshi, 1991) and by using non-polarizing conditions in 4-well plates (this work, 5-7 days) and in different culture supports (6 days in flasks, multiwell plates, culture dishes and glass coverslips, Van Langendonckt et al, 1995). The morphology of cells cultured in 4-well plates is in accordance with that previously described by Van Langendonckt et al (1995) with a procedure similar to that here employed to isolate epithelial cells from bovine oviducts. A low number of mitochondria and the presence of vacuoles without lipidic contents has been described by Van Langendonckt et al (1995), as signs of a decreased cellular activity. These characteristics are similar to those here found in several cells grown on plastic. Coincidentally, the electron-clear vesicles, which have been described in this work, seem to correspond to the vacuoles described by Van Langendonckt et al (1995). This observation suggests that cells which contain electronclear vesicles have a decreased cellular activity and show a tendency to degenerate.

The morphological differences observed between cells cultured in non-polarizing and in polarizing conditions should explain, in part, their different conditioned media embryo developmental rates. The existence, in both culture conditions, of a well developed system of cell-to-cell junctions implicates a strong tissue-like structure, which would improve its functionality (Lodish et al, 1986). The presence of numerous polyribosomes and cisternae of the glandular endoplasmic reticulum and a large Golgi complex with swollen cisternae indicate intense activity in inserts. This suggests high levels of synthesis of proteins to be secreted. Cells cultured in inserts appear flatter and smaller than plastic cultured cells in crosssection, probably because they have formed a multi-layer. Based on the typical organization of epithelial cells lining the oviduct, one should expect to find a single layer of cells grown on the basement support instead of a multi-layer. This is a controversial point which will be undertaken in future investigations. The existence of several cell-layers in the system using the inserts versus the monolayer of the cells grown on plastic may explain a possible higher concentration of embryotrophic factors in IN conditioned medium.

The capacity of the porous membranes mounted in inserts to act as a substrate for a completely confluent BOEC monolayer could relate to the different characteristics of both adjacent conditioned media. The significant differences in $\mathrm{pH}$ observed after $48 \mathrm{~h}$ of conditioning between apical (IN, $\mathrm{pH} 7.27 \pm 0.007)$ and the more acidic basal (OUT, pH $7.12 \pm 0.007$ ) conditioned media provides an initial evidence of a non-free exchanging of molecules and of two independent compartments whose interrelationship is mediated by the cells. The different IN and OUT concentrations of lactate $(752.11 \pm 61.17$ and $515.76 \pm$ $27.07 \mathrm{mg} \cdot \mathrm{mL}^{-1}$ of lactate, respectively) recorded at $24 \mathrm{~h}$ of conditioning indicate essentially the same. After $48 \mathrm{~h}$ of culture, differences in concentrations of lactate between IN and OUT were abolished by the cells and IN and IN + OUT lactate concentrations significantly decreased with regard to those measured $24 \mathrm{~h}$ earlier. This is consistent with a lactate self-consuming activity that could reflect a too long conditioning period for this culture system. Experiments of perfusion of whole oviducts demonstrated 
that a proportion of lactate entering the lumen was synthesized from vascular glucose (Leese and Gray, 1985).

It can be concluded that conditioned medium from apical face of oviductal cells cultured on porous substrate was beneficial for bovine embryo development in vitro. Porous substrate allowed the cells to form a tissue-like structure with a complete morphological and functional cell-confluence. Neither molecules larger than $0.5 \mathrm{kDa}$ nor embryotrophic factors are needed to reach the eight-cell stage in vitro, although further ability to develop the so produced embryos is questionable.

\section{ACKNOWLEDGMENTS}

We wish to thank Dr A Massip and Dr A Van Langendonckt, for their valuable critical review and suggestions, Dr M Martínez-Esteban for his technical support and criticisms, Dr JJ Mangas for HPLC in lactate concentrations, Dr P Ordax and Dr M Turienzo for their help in the selection of slaughterhouse organs.

\section{REFERENCES}

Blanco Gomis D, Morán Gutiérrez MJ, Gutiérrez Alvarez MD, Mangas Alonso JJ (1988) Application of HPLC to characterization and control of individual acids in apple extracts and ciders. Chromatographia 25, 1054-1058

Da Silva R (1994) Influence des cellules epithéliales d'oviducte sur le développement d'embryons bovins in vitro: importance de la membrane basale. Thèse du doctorat, Elev et Ins 260, 17-18

Durnford R, Stubbings RB, Ainsworth L (1994) Evaluation of culture systems containing bovine oviduct epithelial cells or granulosa cells to mature and maintain the developmental competence of bovine oocytes in vitro. Theriogenology 42, 261-272

Ellington JE, Carney EW, Farrel PB, Simkin ME, Foot RH (1990) Bovine 1-2-cell embryo development using a single medium in three oviduct systems. Biol Reprod 43, 97-104

Ellington JE, Ignotz GG, Ball BA, Meyers-Wallen VN, Currie WB (1993) De novo protein synthesis by bovine uterine tube (oviduct) epithelial cells change during co-culture with bull spermatozoa. Biol Reprod 48 (4), 851-856
Eyestone WH, First NL (1989) Co-culture of early cattle embryos to the blastocyst stage with oviductal tissue or in conditoned medium. $J$ Reprod Fertil $85,715-720$

Eyestone WH, Jones JM, First NL (1990) The use of oviduct-conditioned medium for culture of bovine oocytes to the blastocyst stage. Theriogenology 33, 226

Eyestone WH, Jones JM, First NL (1991) Some factors affecting the efficacy of oviduct tissue-conditioned medium for the culture of early bovine embryos. J Reprod Fertil 92, 59-64

Gandolfi F, Moor RM (1987) Stimulation of early embryonic development in the sheep by co-culture with oviductal epithelial cells. J Reprod Fertil 85 , 23-28

Hawk HW, Wall RJ (1994) Improved yields of bovine blastocysts from in vitro-produced oocytes I. Selection of oocytes and zygotes. Theriogenology 41, 1571-1583

Hernández-Ledezma JJ, Villanueva C, Sikes JD, Roberts RM (1995) Comparison of coculture and conditioned medium on expansion and hatching of in vitro derived bovine embryos. Theriogenology 43,33

Joshi MS (1991) Growth and differentiation of the cultured secretory cells of the cow oviduct on reconstituted basement membrane. J Exp Zool 260 (2), 229-238

Leese HJ, Gray MS (1985) Vascular perfusion: a novel means of studying oviduct function. Am J Physiol 248, E 624-E632

Legge M, Sellens MH (1991) Free radical scavengers ameliorate the 2-cell block in mouse embryo culture. Hum Reprod 6, 867-871

Liu LPS, Chan STH, Ho PC, Yeung WSB (1995) Human oviductal cells produce high molecular weight factor that improves the development of mouse embryos. Hum Reprod 10, 2781-2786

Lodish H, Darnell J, Baltimore D (1986) The plasma membrane specialized regions of the plasma membrane. In: Molecular Cell Biology, 1st ed, 599-602

Loutradis D, John D, Kiessling AA (1987). Hypoxanthine causes a 2 -cell block in random-bred mouse embryos. Biol Reprod 36, 311-316

McCaffrey C, McEvoy TG, Diskin MG, Gwazdauskas FC, Kane MT, Sreenan JM (1991) Successful coculture of 1-4-cell cattle ova to the morula or blastocyst stage. J Reprod Fert, 92, 119-124

Mermillod P, Vansteenbrugge A, Wils C, Mourmeaux JL, Massip A, Dessy F (1993) Characterization of the embryotrophic activity of exogenous proteinfree oviduct-conditioned medium used in culture of cattle embryos. Biol Reprod 49, 582-587

Minami N, Utsumi K, Iritani A (1992) Effects of low molecular weigth oviductal factors on the development of mouse one-cell embryos in vitro. $J$ Reprod Fert $96,735-745$ 
Noda Y, Matsumoto H, Umaoka Y, Tatsumi K, Kishi J, Mori T (1991) Involvement of superoxide radicals in the mouse two-cell block. Mol Reprod Dev 28, 356-360

Ouhibi N, Hamidi J, Guillaud J, Menezo Y (1990) Cocultured of 1-cell mouse embryos on different cell supports. Hum Reprod 5, 737-743

Parrish JJ, Susko-Parrish JL, Leibfried-Rutledge ML, Critser ES, Eyestone WH, First NL (1986) Bovine in vitro fertilization with frozen-thawed semen. Theriogenology 25, 591-600

Pinyopummintr T, Bavister BD (1991) In vitromatured/in vitro-fertilized bovine oocytes can develop in morulae/blastocyst in chemically defined, protein-free culture media. Biol Reprod 36, 311-316

Pollard JW, Plante C, King WA, Hansen PJ, Betteridge KJ, Suárez SS (1991) Fertilizing capacity of bovine sperm may be maintained by binding of oviductal apithelial cells. Biol Reprod 44, 102-107

Saeki K, Hoshi M, Leibfried-Rutledge MAL, First NL (1990) In vitro fertilization and development of bovine oocytes matured with commercially available follicle stimulating hormone. Theriogenology 34, 1035-1039
Takahashi Y, First NL (1992) In vitro development of bovine one-cell embryos: influence of glucose, lactate, pyruvate, amino acids and vitamins. Theriogenology 37, 963-978

Tiffin GJ, Rieger D, Betteridge KJ, Yadav BR, King WA (1991) Glucose and glutamine metabolism in pret-attachment cattle embryos in relation to sex and stage of development. J Reprod Fert 93, 125 132

Van Langendonckt A, Vansteenbrugge A, DessyDoizé C, Fléchon JE, Charpigny G, Mermillod P, Massip A, Dessy F (1995) Characterization of bovine oviductal epithelial cell-monolayers cultured under serum-free conditions. In Vitro Cell Dev Biol 31, 664-670

Vansteenbrugge A, Mermillod P, Wils C, Massip A, Dessy F (1992) Respective effect of serum or of oviduct-conditioning in bovine embryo culture media. Arch Int Physiol Biochem Biophys 100, B94

Xu KP, Yadav BR, Rorie RW, Plante L, Betteridge KJ, King WA (1992) Development and viability of bovine embryos derived from oocytes matured and fertilized in vitro and co-cultured with bovine epithelial cells. I Reprod Fertil 94, 33-43 